\title{
PENGAPLIKASIAN SOFT SKILL MEMALUI KURIKULUM AKHLAK DALAM PROGRAM ADIWIYATA DI SD ALAM EL-YAMIEN TUBAN
}

\author{
Lindra Nur Khanifah \\ Universitas Islam Darul 'Ulum Lamongan \\ lindra.10209@gmail.com
}

\begin{abstract}
Abstrak
Pengaplikasian softskill kita tahu dan kita kenal dalam proses pembelajaran biasa kita pahami menjadi pendidikan karakter. Misi Sekolah Dasar Alam El-Yamien Tuban memaparkan tentang adanya pengembangan softskill pada siswa-siswanya. Dalam proses pengembangan diri berakhlakul karimah merupakan bagian dari kurikulum akhlak yang dimiliki sekolah dasar alam el-yamien untuk menerapkan pendidikan karakter yang baik dengan pembiasaan dan keteladanan. Program di lingkup pendidikan dasar menjadikan alam sekitar sebagai sumber belajar juga berhubungan langsung dalam membangun pendidikan karakter, terlebih untuk menanamkan jiwa menyayangi dan peduli terhadap lingkungan sekitar.
\end{abstract}

Kata Kunci : karakter akhlak, adiwiyata, softskill.

\begin{abstract}
The application of soft skills we know and we know in the learning process we usually understand into character education. The mission of El-Yamien Tuban Natural Elementary School explained about the development of soft skills for students. In the process of self-development berakhlakul karimah is a part of the moral curriculum that is owned by el-yamien elementary school to apply good character education with habituation and example. Programs in basic education make the surrounding environment as a source of learning also directly related to building character education, especially to instill a loving soul and care for the surrounding environment.
\end{abstract}

Keywords: moral character, adiwiyata, soft skill 


\section{PENDAHULUAN}

Pendidikan sebagai sebuah proses belajar memang tidak cukup dengan sekedar mengejar masalah kecerdasannya saja. Berbagai potensi siswa atau subyek belajar lainnya juga harus mendapatkan perhatian yang proporsional agar berkembang secara optimal. Oleh karena itu aspek sikap maupun ketrampilan fisik juga perlu mendapatkan kesempatan yang sama untuk berkembang.

Sejalan dengan pengertian kognitif, afektif, psikomotorik tersebut, kita juga mengenal istilah cipta, rasa, dan karsa yang dicetuskan tokoh pendidikan Ki Hajar Dewantara. Konsep ini juga mengakomodasi berbagai potensi siswa. Baik menyangkut aspek cipta yang berhubungan dengan otak dan kecerdasan, aspek rasa yang berkaitan dengan emosi dan perasaan, serta karsa atau keinginan maupun ketrampilan yang lebih bersifat fisik. Kebiasaan berpikir dan bertindak secara konsisten dan terus menerus dapat memungkinkan seseorang untuk menjadi kompeten, dalam arti memiliki pengetahuan, keterampilan, dan nilai-nilai dasar untuk melakukan sesuatu. ${ }^{1}$

Pengetahuan, keterampilan dan sikap yang dikembangkan melalui kurikulum ditujukan untuk mencapai keserasian dan keselarasan dalam kehidupan masyarakat. Dengan terbentuknya proses belajar yang bisa mensinergikan antara apa yang dipelajari dan diikuti dengan apa yang langsung dilakukan akan membuat siswa mampu memahami konsep tanpa perlu kita ragukan.

Banyak penyebab yang melatarbelakangi mengapa integrasi kurikulum belum dapat memberikan hasil seperti yang diharapkan. Faktor penyebabnya dapat berpangkal pada rancangan, pelaksanaan, model pembelajaran, ataupun faktor-faktor pendukung pembelajaran yang lainnya. Dalam proses pembelajaran yang menyangkut materi, metode, media alat peraga dan sebagainya harus juga mengalami perubahan ke arah pembaharuan (inovasi). Dengan adanya inovasi tersebut, seorang guru dituntut untuk lebih kreatif dan inovatif, karena hal ini sangat menentukan keberhasilan siswa terutama pembentukan kecakapan hidup (life skill) siswa yang berpijak pada lingkungan sekitarnya.

Dimulai dari abad 21 ini banyak para pakar pendidikan yang mulai mempopulerkan tentang output siswa yang relevan dengan perkembangan zaman. Karena teori-teori lama yang diajarkan tidak mampu memenuhi tuntutan kerja di masa sekarang. Bisa dimulai dengan terjadinya masalah-masalah pada aktivitas siswa di dalam kelas, antara lain: (1) banyak siswa yang kurang tergerak aktif untuk mencari informasi sendiri dari sumber lain, (2) siswa cenderung hanya duduk, mendengarkan, dan mencatat apa yang disampaikan oleh guru, (3) siswa kurang menghargai ketika ada teman yang mengemukakan pendapat, (4) dalam kelompok, banyak ditemukan siswa yang hanya menggantungkan diri kepada temannya saat mengerjakan tugas yang diberikan oleh guru, (5) Terbentuknya beberapa kelompok bermain (geng) dalam satu kelas, ada kelompok bermain (geng) yang diam dan ada kelompok bermain (geng) yang vokal (banyak bicara).

\footnotetext{
${ }^{1}$ Sholeh Hidayat, Pengembangan Kurikulum Baru, ( Bandung: Remaja Rosdakarya,2013) hlm. 26
} 
Fenomena kemunduran karakter tersebut dapat mengindikasikan adanya dua hal yang saling berkaitan. Pertama, adalah bukti tanda bahwa dunia pendidikan dan pembelajaran di Indonesia saat ni belum mampu membina peserta didiknya dengan kualitas berpikir yang andal. Yang kedua pendidikan moral dan etika belum mendapatkan porsi yang selayaknya atau belum dilakukan dengan metode pembinaan yang efektif dan bermakna. ${ }^{2}$

Realita yang terjadi, pendidikan akhlak yan selama ini dilaksanakan di Indonesia dinilai belum berhasil memperbaiki dan meningkatkan moralitas siswa. Hal ini bisa dimaklumi karena materi pendidikan akhlak yang diselipkan dalam mata pelajaran PKn, Agama, dan lainnya itu hanya sebatas teori tanpa adanya implikasi dari nilai-nilai pendidikan akhlak tersebut.

Selain itu, permasalahan-permasalahan diatas,merupakan pemicu tentang bagaimana mencari solusi yang menekankan pada kemampuan siswa terutama softskill setiap siswa yang memperoleh pengajaran. Keterampilan softskill ini relevan untuk dikembangkan dalam pembelajaran sebuah sekolah alam berbasis Islam, agar kelak para siswa dapat hidup sebagai warga masyarakat, warga negara, warga dunia yang dapat berperan dalam masyarakatnya.

Untuk membelajarkan softskill perlu adanya integrasi kurikulum yang efektif sehingga softskill siswa dapat meningkat. Bisa dilihat di beberapa tempat penyelenggara pendidikan sudah diberikan dengan cukup mumpuni, hal itu bisa dibuktikan dengan telah diselenggarakannya pengembangan softskill di Sekolah Dasar Alam El-Yamien Tuban.

Sekolah ini merupakan lembaga pendidikan dasar dengan konsep alam dan memiliki penciri khas Islami yang sangat kental didirikan pada tahun 2012 hingga saat ini dengan beralamatkan di jalan Brawijaya no. 15 Tuban berdiri pada lahan $1800 \mathrm{~m}^{2}$ dengan sistem pembelajaran full day school. ${ }^{3}$

\section{PEMBAHASAN}

Soft skill terdiri dari gabungan 2 kata yaitu soft dengan makna lunak sedangkan kata selanjutnya skill yang bermakna keahlian ataupun keterampilan. Bisa dipahami bahwa makna softskill itu sendiri merupakan kumpulan dari keterampilan pada setiap individu yang dimiliki secara tersirat atau tak nampak. Terlebih softskill mengacu pada keharmonisanketrampilan. Jika kita bisa mengartikan bahwa hard skill adalah keahlian secara teknis dan pengetahuan yang konkrit dimana dibutuhkan dalam melakukan sebuah tindakan atau pekerjaan, softskilladalah penyempurna dalam melakukan pekerjaan tersebut.

Dengan pembelajaran bermakna, maka pembelajaran di kelas tidak semata - mata menghafal konsep, dan pengetahuan yang bersifat kognitif rendah lainnya serta guru sebagai satu-satunya sumber informasi melainkan akan membawa siswa untuk

\footnotetext{
${ }^{2}$ H.A.R. Tilaar, Agenda Reformasi Pendidikan Nasional, (Magelang: Tera Indonesia, 1999), 94.

${ }^{3}$ Diperoleh dari Brosur Pendaftaran Sekolah Dasar Alam El-Yamien Tuban Tahun Ajaran 20162017
} 
berpartisipasi aktif, karena mereka akan diminta melakukan berbagai tugas, seperti bekerja kelompok, berinteraksi dengan teman, mengajukan pendapat selama pembelajaran.

Pembelajaran yang efektif, efisien, serta menyenangkan diharapkan dapat memotivasi siswa dalam belajar sehingga aktivitas siswa dalam belajar terus meningkat. Pembelajaran tersebut berupaya untuk mengembangkansoftskillsiswa dimana kita lebih paham dengan istilah pendidikan karakter pada siswa.

Berikut ini adalah beberapa atribut yang terkandung dalam softskillyang telah dirumuskan oleh pemerintah berbentuk nilai-nilai yang akan diajarkan dan ditanamkan pada proses pendidikan berlangsung, berikut penjelasannya: ${ }^{4}$

\section{Tabel 1.}

\begin{tabular}{|c|c|}
\hline Nilai & Deskripsi \\
\hline 1. Religius & $\begin{array}{l}\text { Sikap dan perilaku yang patuh dalam melaksanakan ajaran agama } \\
\text { yang dianutnya, toleran terhadap pelaksanaan ibadah agama lain, dan } \\
\text { hidup rukun dengan pemeluk agama lain. }\end{array}$ \\
\hline 2. Jujur & $\begin{array}{l}\text { Perilaku yang didasarkan pada upaya menjadikan dirinya sebagai } \\
\text { orang yang selalu dapat dipercaya dalam perkataan, tindakan dan } \\
\text { pekerjaan. }\end{array}$ \\
\hline 3. Tole & $\begin{array}{l}\text { Sikap dan tindakan yang mengahrgai perbedaan agama, suku, etnis, } \\
\text { pendapat, sikap dan tindakan orang lain yang berbeda dari dirinya. }\end{array}$ \\
\hline 4. Disi & $\begin{array}{l}\text { Tindakan yang menunjukkan perilaku tertib dan patuh pada berbagai } \\
\text { ketentuan dan peraturan. }\end{array}$ \\
\hline 5. Kerja & $\begin{array}{l}\text { Perilaku yang menunjukkan upaya sungguh-sungguh dalam } \\
\text { mengatasi berbagai hambatan belajar dan tugas, serta menyelesaikan } \\
\text { tugas dengan sebaik-baiknya. }\end{array}$ \\
\hline 6. Kreatif & $\begin{array}{l}\text { Berpikir dan melakukan sesuatu untuk menghasilkan cara atau hasil } \\
\text { baru dari sesuatu yang telah dimiliki. }\end{array}$ \\
\hline 7. Mandiri & $\begin{array}{l}\text { Sikap dan perilaku yang tidak mudah tergantung pada orang lain } \\
\text { dalam menyelesaikan tugas-tugas. }\end{array}$ \\
\hline 8. Demokratis & $\begin{array}{l}\text { Cara berpikir, bersikap, dan bertindak yang menilai sama hak dan } \\
\text { kewajiban dirinya dan orang lain. }\end{array}$ \\
\hline $\begin{array}{l}\text { 9. Rasa ingin } \\
\text { tahu }\end{array}$ & $\begin{array}{l}\text { Sikap dan tindakan yang selalu berupaya untuk mengetahui lebih } \\
\text { mendalam dan meluas dari sesuatu yang dipelajarinya, dilihat dan } \\
\text { didengar. }\end{array}$ \\
\hline $\begin{array}{l}\text { 10. Semangat } \\
\text { kebangsaan }\end{array}$ & $\begin{array}{l}\text { Cara berpikir, bertindak, dan berwawasan yang menempatkan } \\
\text { kepentingan bangsa dan negara di atsa kepentingan driri dan }\end{array}$ \\
\hline
\end{tabular}

${ }^{4}$ Badan Penelitian dan Pengembangan Pusat Kurikulum, Pengembangan Pendidikan Budaya dan Karakter Bangsa, ( Kementrian Pendidikan Nasional, 2010), hlm. 9-10 


\begin{tabular}{|c|c|}
\hline & elompoknya. \\
\hline 11. Cinta $t$ & $\begin{array}{l}\text { Cara berpikir, bersikap dan berbuat yang menunjukkan kesetiaan, } \\
\text { kepedulian, dan penghargaan yang tinggi terhadap bahasa, } \\
\text { lingkungan fisik, sosial, budaya, ekonomi dan politik bangsa. }\end{array}$ \\
\hline $\begin{array}{l}\text { 12. Menghargai } \\
\text { prestasi }\end{array}$ & $\begin{array}{l}\text { Sikap dan tindakan yang mendorong dirinya untuk menghasilkan } \\
\text { sesuatu yang berguna bagi masyarakat, dan mengakui serta } \\
\text { menghormati keberhasilan orang lain. }\end{array}$ \\
\hline $\begin{array}{l}\text { 13. Bers } \\
\text { koml }\end{array}$ & $\begin{array}{l}\text { Tindakan yang memperlihatkan rasa senang, berbicara, bergaul, dan } \\
\text { bekerja sama dengan orang lain. }\end{array}$ \\
\hline 14. Cint & $\begin{array}{l}\text { Sikap, perkataan, dan tindakan yang menyebabkan orang lain } \\
\text { merasa senang dan aman atas kehadiran dirinya. }\end{array}$ \\
\hline $\begin{array}{l}\text { 15. Gem } \\
\text { mem }\end{array}$ & $\begin{array}{l}\text { Kebiasaan menyediakan waktu untuk membaca berbagai bacaan } \\
\text { yang memberikan kebajikan bagi dirinya. }\end{array}$ \\
\hline $\begin{array}{l}\text { 16. Peduli } \\
\text { lingkungan }\end{array}$ & $\begin{array}{l}\text { Sikap dan tindakan yang selalu berupaya mecegah kerusakan pada } \\
\text { lingkungan alam di sekitarnya, dan mengembangkan upaya-upaya } \\
\text { untuk memperbaiki kerusakan alam yang sudah terjadi. }\end{array}$ \\
\hline 17. Peduli sosial & $\begin{array}{l}\text { Sikap dan tindakan yang selalu ingin memberi bantuan pada orang } \\
\text { lain dan maysarakat yang membutuhkan. }\end{array}$ \\
\hline $\begin{array}{l}\text { 18. Tanggung } \\
\text { jawab }\end{array}$ & $\begin{array}{l}\text { Sikap dan perilaku seseorang untuk melaksanakan tugasa dan } \\
\text { kewajibannya, yang seharusnya dia lakukan terhadap diri sendiri, } \\
\text { masyarakat, lingkungan (alam, sosial dan budaya), negara dan } \\
\text { Tuhan Yang Maha Esa. }\end{array}$ \\
\hline
\end{tabular}

Berdasarkan pada konsep pengembangan softskill yang telah dipaparkan Diana's, Sekolah Dasar Alam El-Yamien Tuban mampu dikategorikan menjadi Salah satu lembaga pendidikan professional yang mendukung Dan berupaya penuh mengembangkan soft skill para siswanya.

Bisa dilihat misi Sekolah Dasar Alam El-Yamien Tuban yaitu "Sekolah Dasar ElYamien adalah sekolah yang mempersiapkan anak didik untuk menjadi manusia pembelajar yang aktif, kreatif, menyenangkan serta menghargai nilai nilai pekerti yang berbasis pada norma agama dan menghargai lingkungan hidupnya". 5

Kurikulum yang digunakan di Sekolah Dasar Alam El-Yamien merupakan integrasi dari kurikulum Depdiknas yaitu kurikulum 2013 , kurikulum sekolah alam Dan kurikulum akhlaq sehingga mampu menghasilkan proses pendidikan dasar yang bermakna Dan mampu memperoleh prestasi akademik yang mumpuni Dan berdaya saing. Pada struktur pembelajaran yang dilakukan terkandung beberapa kegiatan

\footnotetext{
${ }^{5}$ Data berasal dari Brosur Pendaftaran Sekolah Dasar Alam El-Yamien Tuban Tahun ajaran 20162017
} 
pengembangan diri yang bisa menggali kemampuan soft skill setiap siswanya dengan konsisten.

Proses pengembangan diri ditujukan untuk pengembangan karakter siswanya, untuk menjadi solusi diri sendiri dalam menghadapi persoalan pada diri siswa itu sendiri, persoalan masyarakat di lingkungan tempat tinggalnya, serta persoalan kebangsaan dan kenegaraan yang terjadi. Dijelaskan lagi bahwa pengembangan diri yang dilakukan bukan merupakan sebuah mata pelajaran yang diampu oleh siswa, namun pengembangan diri adalah sebuah proses atau Kegiatan yang dilakukan dengan tujuan memberi kesempatan siswa untuk mengenal kemampuan Siri, mengembangkan dan mengekspresikan kemampuan dari diri setiap sides sesuai demean bakat, Minat, kebutuhan di masyarakatsesuaidengan apa yang sekolah miliki Dan harapkan.

Pengembangan diri yang termasuk dalam kurikulum Sekolah Dasar Alam El-Yamien Tuban adalah sebagai berikut:

a. Kegiatan Pelayanan Bimbingan dan Konseling, meliputi :

1 Menangani permasalahan-permasalahan yang dialami siswa ketika proses pembelajaran

2 Menangani permasalahan-permasalahan sosial yang dialami siswa

3 Mengamati perkembangan siswa melalui home visit

4 Menangani permasalahan pembiayaan sekolah

b. Kegiatan pengembangan diri siswa yang telah disepakati oleh sekolah antara lain :

1 Pramuka

2 Baca Tulis Al-Quran

3 Bela diri (Karate)

4 Bercocok Tanam

5 Berenang

6 Memanah

7 Hadroh

c. Kegiatan pengembangan diri siswa yang bersifat dilakukan secara rutin :

1 Upacara Bendara Merah Putih

2 Salat Dhuha

3 Hafalan surat-surat pendek

4 Hafalan Asmaul Husna

5 Salat Berjamaah ketika waktu Dhuhur

6 Berdoa di awal dan di akhir proses pembelajaran

d. Kegiatan pengembangan diri siswa yang bersifat spontan (tidak terduga) :

1 Mengucapkan salam

2 Berjabat tangan dengan ustad dan ustadzah ketika memasuki gerbang sekolah

3 Pemeriksaan kuku, rambut serta kebersihan seragam

4 Membuang bungkus sisa makanan ke tempat sampah yang telah disediakan

5 Memcuci tangan dan kaki sebelum dan sesudah makan 
6 Melaporkan jika menemukan barang temannya yang hilang atau sebaliknya jika merasa kehilangan barang

7 Menjenguk teman yang sedang tertimpa musibah (sakit, dll)

8 Ta'ziah dan praktik salat jenazah

e. Kegiatan yang bersifat pembiasaan dalam keteladanan antara lain:

1 Senyum

2 Sapa, sopan dan santun

3 Salam

4 Berbagi sesuatu dengan teman

5 Berpakaian bersih dan rapi

6 Datang dan pulang sekolah tepat waktu

Akhlak berasal dari bahasa Arab "Akhla>q" yang merupakan jamak dari "khuluq" yang berarti adat kebiasaan $(a l$ - ' $a>d a h)$, perangai, tabiat, watak, adab atau sopan santun dan agama. Menurut ulama Salaf, akhlak adalah kemampuan jiwa untuk melahirkan suatu perbuatan secara spontan, tanpa adanya proses berpikir dan paksaan yang terjadi. Sering pula yang dimaksud akhlak adalah semua perbuatan yang lahir atas dorongan jiwa berupa perbuatan baik atau buruk. ${ }^{6}$

Upaya peningkatan kualitas pendidikan akhlak adalahdengan terus menerus mengembangkan kurikulum pendidikan akhlak sesuai kondisi dan kebutuhan masyarakat. Metode pendidikan akhlak yang efektif yaitu dengan adanya keteladanan, pembiasaan, nasehat, perhatian dan hukuman. Karena pada usia sekolah siswa cenderung akan lebih mengena jika ke lima metode tersebut diaplikasikan.

Mengingat kembali bahwa softskill tidak bisa dikembangkan melalui tahap kurikulum tertulis dan proses pembelajaran formal, softskill tetap mampu dilakukan melalui penerapan pendidikan akhlak (moral). ${ }^{7}$

Kegiatan Pengembangan diri yang dilaksanakan dengan Kurikulum Akhlak di Sekolah Dasar Alam El-Yamien Tuban adalah sebagai berikut : ${ }^{8}$

a. Kegiatan rutin seperti : upacara bendera merah putih setiap hari Senin, berjamaah salat Dhuha, sebelum memulai dan mengakhiri pelajaran selalu diawali dan diakhiri dengan doa, selalu mengucap syukur

b. Kegiatan Spontan seperti :menjenguk teman maupun ustad/ustadzah yang terkena musibah (sakit,dll), melaporkan jika menemukan barang yang telah hilang maupun sebaliknya, menghargai dan bersikap menerima jika terjadi perbedaan pendapat dengan temannya, melakukan kegiatan bersama-sama.

\footnotetext{
${ }^{6}$ Suwito, Filsafat Pendidikan Akhlak Ibn Miskawaih ( Yogyakarta: Belukar, 2004), 31.

7 Tim Pelatihan Soft Skill Pada Dosen, Pengembangan Soft Skill Dalam Proses Pembelajaran di Perguruan Tinggi, (Direktorat Akademik Dirjen Pendidikan Tinggi Depdiknas, 2008), 24.

${ }^{8}$ Dokumen inti Kurikulum 2013 Sekolah Dasar Alam El-Yamien Tuban
} 
c. Kegiatan keteladanan yang diwujudkan dalam perilaku dan hal-hal baik yang dilakukan oleh warga sekolah dan dapat diteladani oleh para siswa, yaitu : datang ke sekolah tepat waktu,dengan mengenakan seragam yang bersih dan rapi, kemudian menyapa dan memberi salam serta berjabat tangan dengan ustad maupun ustadzah yang berjaga di depan sekolah, selalu bersikap sopan dan santun pada semua orang, selalu membuang bungkus makanan yang telah habis di tempat sampah.

Pada kenyataannya, di Sekolah Dasar Alam El-Yamien Tuban, bentuk ekstrakulernya juga beragam, yaitu diadakannya salat Dhuha dan salat Dhuhur berjamaah. Hal ini bertujuan agar siswa mampu mengembangkan kepribadian yang baik tanpa mengurangi porsi mengembangkan nilai akademik siswa itu sendiri. Bila siswa sudah terbiasa dengan melakukan salat berjamaah maka dipastikan akan membentuk sikap disiplin siswa itu sendiri ditambah dengan bertambahnya sikap religius siswa terhadap Tuhannya.

Sekolah Dasar Alam El-Yamien Tuban adalah lembaga pendidikan pada tingkat dasar yang mengimplementasikan kurikulum berbasis alam. Dimana kurikulum ini mengedepankan karakter dan akhlak siswa juga sekaligus mengembangkan aspek kognitif karena melalui pembelajaran yang asyik. Ketika suatu sekolah sudah menyertakan kurikulum alam pasti terdapat unsur progran Adiwiyata yang harus dijalankan. Karena program Adiwiyata merupakan bentuk penghargaan sekolah yang berwawasan lingkungan hidup.

Program Adiwiyata yang bersinergi dengan kurikulum 2013 dan kurikulum akhlak dilakukan demi tercapainya pendidikan untuk siswa yang memberikan aplikasi langsung terhadap alam. Yang berarti bahwa siswa juga mampu memahami tentang apa yang telah diberikan terhadap alam untuk kita serta bagaimana karakter peduli terhadap alam dan lingkungan demi keberlangsungan umat manusia.

Program Adiwiyata dikembangkan berdasarkan norma-norma dalam peri kehidupan yang antara lain meliputi : kebersamaan, keterbukaan, kesetaraan, kejujuran, keadilan, dan kelestarian fungsi lingkungan hidup dan sumber daya alam. ${ }^{9}$

Sangat banyak manfaat yang diperoleh sekolah sekolah maupun warga sekolah dengan mengikuti program Adiwiyata. Setidaknya ada 5 manfaat mengikuti program Adiwiyata, yaitu : ${ }^{10}$

${ }^{9}$ Ellen Landriany, Implementasi Kebijakan Adiwiyata Dalam Upaya Mewujudkan Pendidikan Lingkungan Hidup di SMA Kota Malang" dalam Jurnal Kebijakan dan Pengembangan Pendidikan Volume 2, Nomor 1, Januari 2014: 82-88

${ }^{10}$ Sungkowo, Konsep Pendidikan Lingkungan Hidup Pada Jalur Pendidikan Dasar dan Menengah, (Jakarta:Disdakmen, 2005) 
1 Mendukung percepatan pencapaian 8 Standar Nasional Pendidikan ( standar isi, proses, kompetensi lulusan, pendidik dan tenaga kependidikan, sarana dan prasarana, pengelolaan pembiayaan dan penilaian) sebagaimana diatur dalam PP No. 19 Tahun 2006 tentang Standar Nasional Pendidikan.

2 Meningkatkan efisiensi penggunaan dana operasional sekolah melalui penghematan dan pengurangan konsumsi dari berbagai sumber daya dan energi.

3 Menciptakan kebersamaan warga sekolah dan kondisi belajar mengajar yang lebih nyaman dan kondusif.

4 Menjadi tempat pembelajaran tentang nilai-nilai pemeliharaan dan pengelolaan lingkungan hidup yang baik dan benar bagi warga sekolah dan masyarakat sekitar.

5 Meningkatkan upaya perlindungan dan pengelolaan lingkungan hidup melalui kegiatan pengendalian pencemaran, pengendalian kerusakan dan pelestarian fungsi lingkungan di sekolah.

Di Indonesia untuk mengoptimalkan percepatan pengembangan Pendidikan Lingkungan Hidup khusunya jalur pendidikan formal pada jenjang pendidikan dasar dan menengah, maka pada tanggal 21 Februari 2006 Kementrian Lingkungan Hidup dan Kementrian Pendidikan dan Kebudayaan telah mencanangkan Program Adiwiyata dengan tujuasn mendorong dan membentuk sekolah Peduli dan Berbudaya Lingkungan yang mampu berpartisipasi dan melaksanakan upaya pelestarian lingkungan dan pembangunan berkelanjutan bagi kepentingan generasi sekarang maupun yang akan datang. ${ }^{11}$

Beberapa pembiasaan dalam menjaga lingkungan yang tertata telah berjalan sesuai dengan harapan, dengan keberlangsungan pembiasaan ini diharapkan karakter peduli lingkungan akan melekat dengan baik pada pribadi siswa hingga nanti diaplikasikan setelah berada di lingkungan kerja ketika dewasa nanti. Kepedulian terhadap lingkungan adalah bentuk softskill yang tidak bisa dianggap remeh. Karena dengan kita peduli terhadap apa yang ada disekitar kita menandakan bahwa kita juga peduli terhadap kebersihan diri pribadi.

Proses pembelajaran yang efektif baik secara teori dan aplikasi sangat bergantung pada waktu pembelajaran. Maka dari itu oleh pihak Sekolah Dasar Alam El-Yamien Tuban menerapkan sistem sekolah full day school.

Sistem full day school merupakan sebuah sistem pembelajaran di sekolah dimulai waktu pagi hingga sore hari. Rentan waktu yang digunakan rata-rata 7-8 jam per hari. Dengan sistem tersebut diharapakan siswa mampu belajar dengan aktif dan memperoleh pembelajaran tidak setengah-setengah. Dalam program fullday school ada garis-garis besar dalam pelaksanakannya yaitu sebagai berikut: ${ }^{12}$

${ }^{11} \mathrm{Ibid}$

${ }^{12}$ Sehudin, Pengaruh Pelaksanaan Pembelajaran Fullday School terhadap Akhlak Peserta Didik. Tesis Jurusan PAI Fakultas Tarbiyah. (Surabaya : IAIN Sunan Ampel, 2005) 17 
1 Membentuk sikap yang Islami

a. Pembentukan sikap yang Islami

1) Pengetahuan dasar tentang Iman, Islam dan Ihsan

2) Pengetahuan dasar tentang akhlak terpuji dan tercela

3) Kecintaan kepada Allah dan Rasulnya

4) Kebanggan kepada Islam dan semangat memperjuangkan

b. Pembiasaan berbudaya Islam

1) Gemar beribadah

2) Gemar belajar

3) Displin

4) Kreatif

5) Mandiri

6) Hidup bersih dan sehat

7) Adab-adab Islam

2 Penguasaan Pengetahuan dan Keterampilan

a. Pengetahuan materi-materi pokok program pendidikan

b. Mengetahui dan terampil dalam beribadah sehari-hari

c. Mengetahui dan terampil baca tulis Al-Quran

d. Memahami secara sederhana isi kandungan amaliyah sehari-hari.

Dengan adanya garis besar pelaksanaan program fullday school maka sangat jelas tujuan yang akan tercapai dan diharapkan. Full day school memberikan gambaran lingkungan pendidikan yang positif, dengan adanya interaksi antar warga sekolah yang ada , ustad dan ustadzah yang memberikan keteladan, kebiasaan-kebiasaan Islami yang mencerminkan hidup bersosialisasi, serta adanya sanksi hukuman memberi efek jera pada suatu program pendidikan yang baik.

Pada konsep pengembangan diri khususnya adalah karakter pribadi setiap siswa tidak mampu dilihat hasilnya secara signifikan dalam kurun waktu yang pendek. Tapi, kita sebagai pihak dewasa wajib untuk melakukan evaluasi melalui pengamatan secara berkala ketika proses pembelajarannya berlangsung. Kemampuan yang dilihat adalah :

a. Kemampuan Intrapersonal

Dalam kegiatan pembelajaran di sekolah dapat dicermati kemampuankemampuan ini melalui pemantauan secara personal dari setiap sisi.

1 Aktifitas ibadah siswa untuk mengetahui kepribadian Islamnya, loyalitasnya, tanggung jawab terhadap agama yang dianutnya.

2 Aktifitas harian untuk mengetahui kemampuan manajemen waktu siswa tersebut, kedisiplinannya, keueltannya, serta semangat belajarnya.

3 Usaha mandiri untuk mengetahui kemampuan kreatifitasnya, kehebatan idenya dan kebulatan tekadnya. 


\section{b. Kemampuan Interpersonal}

1 Sosialisasi dengan temannya, hal seperti ini mampu digunakan untuk mengetahui kemampuan bercakap, kemampuan persuasi, kemampuan bersikap dengan pihak lain.

2 Keaktifan dalam kelas, dasar dalam pembelajaran bisa mengindikasikan tentang kecerdasan sensori, visual, verbal, kinestetik, jiwa kepemimpinan, rasa tanggung jawab dan keberaniannya serta mampu mengambil keputusan secara bijak.

3 Aktivitas sehari-hari, dapat mengetahui tipe karakter manusia yang mampu bersosialisasi dengan baik dan jiwa peduli dan kepekaan terhadap hal lain disekitarnya.

\section{KESIMPULAN}

Pengaplikasian softskill di Sekolah Dasar Alam El-Yamien Tuban tercermin dari visi misinya, yang diwujudkan melalui kurikulum akhlak dan ekstrakulikuler. Kurikulum akhlak itu sendiri merupakan nilai-nilai karakter serta norma Islami yang diajarkan melalui kurikulum non tulis. Strukturalisasi kurikulum terdiri dari 3kurikulum yaitu kurikulum 2013, kurikulum akhlak, dan kurikulum sekolah alam. Dimana ketiga kurikulum tersebut bersinergi dalam proses pengembangan softskill sebagai proses pengembangan diri. Proses pengembangan diri ditujukan sebagai upaya pengembangan karakter siswa agar mampu menghadapi tantangan globalisasi, mengatasi segala tantangan hidup serta mengajarkan hal-hal baik terhadap orang sekitar dan berdampak pada lingkungan yang baik pula. Proses pembiasaan diri yang dilakukan oleh siswa diantaranya pembiasan menyapa, menolong teman, menanam tanaman, solat berjamaah. Hal itu mampu dilaksanakan menjadi sebuah pembiasaan dan keteladanan. Program Adiwiyata pada sekolah berbasis Alam ammpu memebri damak yang positif terhadap siswanya. Mulai dari rasa memiliki terhadap alam, rasa mencintai dan peduli tentang apa yang terjadi dengan alam, dan bagaimana cara menjaga alam agar tetap bisa kita manfaatkan hingga masa mendatang. Beberapa program sekolah yang diwujudkan dalam pembelajaran langsung dengan alam turut serta dalam menanamkan serta mengaplikasikan karakter dan nilai peduli lingkungan di Sekolah Dasar Alam El-Yamien Tuban. Karena Sekolah Dasar Alam El-Yamien Tuban juga merupakan sebuah sekolah dengan program fullday school yang mampu menyeimbangkan antara pembelajaran berbasis teoristis dengan pembelajaran aksi nyata. 


\section{DAFTAR PUSTAKA}

Brosur Pendaftaran Sekolah Dasar Alam El-Yamien Tuban Tahun Ajaran 2016-2017 Dokumen K13 Sekolah Dasar Alam El-Yamien Tuban

Anderson and Krathwohl. (2010). Kerangka Landasan untuk Pembelajaran, Pengajaran, dan Asesmen. Yogyakarta: Pustaka Pelajar.

Arends, Richard. (2012). Learning to Teach. New York: McGraw-Hill.

Arsyad, Ashar. (2006). Media Pembelajaran. Jakarta: Raja Grafindo Persada.

Arikunto, Suharsismi. 2010. Prosedur Penelitian Suatu Pendekatan Praktik. Jakarta: Rineka Cipta

Atinah, Sri. (2011). Strategi Pembelajaran di SD. Jakarta: Universitas Terbuka.

Balitbang Puskur, Pengembangan Pendidikan Budaya dan Karakter Bangsa,( Kementrian Pendidikan Nasional, 2010)

Budiningsih, Asri. (2012). Belajar dan Pembelajaran. Jakarta: Rineka Cipta.

Dimyati dan Mudjiono. (2002). Belajar dan Pembelajaran. Jakarta: Rineka Cipta.

Hidayat, Sholeh, Pengembangan Kurikulum Baru, Bandung: remaja Rosdakarya, 2013.

Holladay, Jennifer. (2013). "The Character of Our Content: A Parent Confronts Bias in Early Elementary Literature”. Journal Articles. Vol 27 No.2, p42-45.

Howe, A,C. And Jones, L. (1993). Engaging Children in Science. N. Y: Merill

Landriany, Ellen. (2014). Implementasi Kebijakan Adiwiyata Dalam Upaya Mewujudkan Pendidikan Lingkungan Hidupdi SMA kota Malang. Jurnal Kebijakan dan Pengembangan Pendidikan Volume 2, Nomor 1, Januari 2014.

Saila, Illah, Pengembangan Soft Skill di Perguruan Tinggi, Tim Kerja Pengembangan Soft Skill Direktorat Jendral Pendidikan Tinggi, 2008.

Sehudin, (2005) Pengaruh Pelaksanaan Pembelajaran Fullday School terhadap Akhlak Peserta Didik. Tesis Jurusan PAI Fakultas Tarbiyah IAIN Sunan Ampel. Surabaya

Slavin, Robert E. (2008). Psikologi Pendidikan: Teori dan Praktik. Jakarta: PT Indeks.

Sungkowo. (2005). Konsep Pendidikan Lingkungan Hidup Pada Jalur Pendidikan Dasar dan Menengah. Jakarta: Disdakmen. 